\title{
Risk multipliers for severe food anaphylaxis
}

\author{
Peter K Smith ${ }^{1 *}$, Jonathan O'B Hourihane ${ }^{2}$ and Phil Lieberman ${ }^{3}$
}

\begin{abstract}
Anaphylaxis is a severe, life threatening allergic reaction. In most fatal cases of food anaphylaxis, the fatality is not due merely to a simple, linear relationship between the allergen and exposure in a sensitized individual. Compounding factors such as the allergic disease burden - particularly the presence of asthma; comprehension of the potential severity of an event, training in the appropriate use of epinephrine, and emerging metabolic factors should be considered when assessing risk and establishing management strategies. This paper reviews the factors that contribute to the risk of severe anaphylactic events and provides a framework for the ongoing management of patients at risk of severe food allergy.
\end{abstract}

\section{Review}

Death from food anaphylaxis remains a rare but tragic event [1]. The majority of fatal food anaphylaxis involves children and young adults [1-3]. In most fatal cases there is a combination of several known risk factors, which often could have been individually mitigated. The purpose of this review is to highlight known factors that increase the risk for severe allergic reactions to food and to present, in a practical and visual manner, strategies that can be used to identify and deal with these factors when taking a history, examining and planning management for individuals with food allergy.

Anaphylaxis is a serious, life-threatening, generalized hypersensitivity reaction that can occur via immunologic (either IgE-dependent or IgE-independent) or nonimmunologic mechanisms [4]. Effective management of potentially life-threating reactions involves review by an allergist to identify causative allergens (and other allergic risks to help reduce exposure), and the prescription of and training in the use of epinephrine [5]. This referral for an evaluation should best occur at the emergency care setting where, currently, under-diagnosis of anaphylaxis is an issue [6]. The following aspects need to be highlighted as particular risk factors for anaphylaxis, with an emphasis on food anaphylaxis.

\section{Dose and type of allergen}

With IgE dependent reactions it is considered axiomatic that the dose of allergen that the sensitized individual is

\footnotetext{
* Correspondence: pksm@mac.com

'Griffith School of Medicine, Gold Coast, Australia

Full list of author information is available at the end of the article
}

exposed to determines the severity of the reaction $[7,8]$. However it should be appreciated that a threshold dose for symptoms can vary for an individual and between individuals. The concealment of allergen (hidden allergen) can result in delayed recognition of an allergic food and increase dose exposure. The median time from ingestion of peanut to experiencing symptoms has been reported to be as short as 3 minutes [9]. In adult subjects undergoing repeat peanut challenges, an increase in the lipid matrix of a concealed peanut biscuit led to higher dosing before the patient developed symptoms, and consequently they experienced more severe allergic and anaphylactic reactions [10]. Other concealment/dosing factors may include spicy foods where itch and burning from spices could mimic allergic symptoms. Case series have reported an apparent effect of alcohol/sedating medication consumption, where symptom recognition is reduced, though there are no published studies on dosethresholds related to these latter factors. The type of allergen contributes to concealment and exposure risk. In a threshold dose study, peanut caused more severe reactions than other foods studied (hazelnut, egg and milk) [11]. In a study investigating the correlation of dose with severity of the reaction in a community setting and the threshold dose of peanut in a double blind placebo controlled challenge, the amount of the dose did not relate significantly to either the severity of the reaction or the dose of peanut reportedly consumed in the community [12]. This suggests that there are very important co-factors that influence the severity of food allergic reactions outside the controlled clinical setting of a formal food challenge [13]. 
Age

Youth-specifically teenage years and being a young adult-is a risk factor for fatal reactions $[1-3,14,15]$. The expected attributable social and emotional contributing factors include risk-taking behavior with eating, disease denial or treatment non-compliance (not carrying an epinephrine auto-injector and poor asthma control) [16]. Although not specific to food allergy, Brown et al. reported that older age was associated with more severe hypoxemia with anaphylaxis episodes [17]. In a peanut threshold dose study, adults with peanut allergy had more severe reactions than children [11]. This finding has very significant implications, for the majority of patients with peanut allergy do not grow out of their sensitivity.

\section{Late or absent treatment}

Failure to use epinephrine, or to use it promptly is considered to be an important and avoidable factor in fatal reactions [5, 17-21]. Combining the data of Bock and Pumphrey in cases of fatal food anaphylaxis, only 5 of 80 patients had administered epinephrine appropriately [2, 3]. Intramuscular epinephrine in the community setting is the standard of care for anaphylaxis, as inhaled epinephrine devices are unreliable in children [22] and subcutaneous epinephrine takes up to 30 minutes to achieve significant serum levels [23, 24].

\section{Asthma}

Asthma is probably the most significant risk factor for death from food allergy anaphylaxis, with case series finding $69-100 \%$ of patients having pre-existing asthma $[2,3,5,13,18-21,25]$. Summers and colleagues reported that allergic burden contributes to the severity of allergic reactions in patients with nut anaphylaxis [26]. In patients with severe asthma the risk for life-threatening bronchospasm during nut associated anaphylaxis was increased 6.8 fold, although this relative risk was only 2.7 times for those patients with mild asthma. With active allergic airway disease, an increase in mast cells, basophils, neutrophils and eosinophils appear in the airways [27-30]. Cornell described a clinical entity of airway "priming" [31, $32]$, where pollen-allergic patients experience a greater allergic reaction (and with smaller doses of allergens) at the end of the pollen season than at the start. Priming has been demonstrated experimentally $[27,28]$ and can be reduced with the use of nasal steroids [33]. Priming increases symptoms to both the priming antigen as well as non-priming antigens and non-allergic stimuli [32]. We hypothesize that the Summers et al. report, reflects increased effector cell activity with allergic disease burden due to "priming", which resulted in more severe food allergy reactions. Swedish children with inhalant allergies suffer food anaphylaxis more commonly in their relevant pollen season, compared to children without pollen allergy, whose event rate is more stable through the year [34]. Oral allergy syndrome (also called secondary food allergy or pollen-food allergy) may increase in severity in high pollen season [35]. Whilst oral allergy syndrome is often regarded as mild disease, severe reactions including anaphylaxis can occur [36].

\section{Past history of severe allergic reactions}

A history of severe allergic events including anaphylaxis has been identified as a risk factor for fatal events due to food and future severe allergic reactions [19, 37]. A history of anaphylaxis also appears to influence both the dose of an allergen tolerated in patients receiving food allergy oral immunotherapy and the risk of severe reactions during oral food immunotherapy [38]. It should be stressed that the about half of a UK series of food anaphylaxis deaths occurred in patients with a history of mild reactions, thus there can be little reassurance based on a history of previous mild reactions [39].

\section{Allergic disease burden}

In a case series of patients with nut allergy, severe rhinitis was associated with a 3.8 fold increased risk for severe pharyngeal edema and severe eczema correlated with a 3.1- fold increased risk of impaired consciousness (presumably hypotension) with anaphylaxis events [26]. Although aging is physiological rather than a "disease", increasing age has been correlated with a higher risk of severe cardiovascular symptoms $[17,40]$.

\section{Physiological and medication}

Multiple allergic mediators (e.g., tryptase, histamine, platelet activating factor, IL-2, IL-6, IL-10 and soluble tumor necrosis factor receptor I), have been correlated with severity of anaphylactic reactions [17, 39-41]. These mediators are products of the allergic reaction, rather than being risk factors for anaphylaxis.

Variants in the catabolic capacity of two enzymes have been correlated with risk for severity of anaphylaxis [17, 26]. Patients with serum angiotensin converting enzyme 1 (ACE) levels in the lower quartile of normal $(<37.0 \mathrm{mmol} /$ L) have been reported to have a 9.6 (1.6-57) - fold risk of severe pharyngeal edema when experiencing anaphylaxis from a nut source compared to those in the higher quartile [26]. In a study of all forms of anaphylaxis, platelet activating factor acetyl hydrolase activity (also known as Lipoprotein-associated phospholipase A2) was found to be associated with severe reactions in a proportion of patients [17]. Serum PAF levels have also been linked to anaphylaxis severity [42]. Platelet activating factor acetyl hydrolase is responsible for PAF degradation in plasma [43]. ACE is the main protease responsible for bradykinin catabolism [44]. There are two allelic forms of ACE, and 
increased expression of the gene for the "I" allele has been associated with more severe food allergy [45].

While medications cause most healthcare related episodes of anaphylaxis, only aspirin has been reported to be related to food dependent exercise induced anaphylaxis $[46,47]$. Beta-blockers, cox-inhibitors and ACE inhibitors have been reported as possible contributors to the severity of all forms of anaphylaxis [13, 40], and both Beta-blockers and ACE inhibitors have been associated with mast cell priming [48]. Gliptins (which are used in diabetes and inhibit a serine protease, have been reported to augment ACE induced angioedema [49]. Aspirin may cause increased gastrointestinal permeability, and therefore the rapidity and amount of allergen levels reaching the submucosa/systemic circulation. A $500 \mathrm{mg}$ dose of aspirin has been reported to increase the likelihood of a positive food challenge in patients with wheat dependent exercise induced anaphylaxis [47]. While not specific for food, Brown et al. reported that use of cardiovascular medications correlated with age but was not associated with additional risk for reaction severity [17].

Menstruation may be another physiological state that destabilizes the allergic status of an individual and the relation of anaphylactic episodes to the menses should be considered when appropriate.

\section{Exercise}

Exercise can cause anaphylaxis directly and is a co-factor for food anaphylaxis, best defined as food dependent exercise induced anaphylaxis (FDEIA). Wheat-derived omega 5 gliadin is the antigen most commonly recognized as causing this syndrome [50, 51]. A US series reported shellfish crustaceans to be the allergen in $37 \%$ of cases of FDIEA [52]. Because of the multi-factorial nature of this condition, the diagnosis can be difficult to make (the patient often experiences multiple severe attacks over a prolonged time) because the patient can tolerate the food remote from exercise without symptoms. It is proposed that exercise increases GI permeability and/or allergen digestion, so the patient is exposed to greater levels of antigen [35, 53]. Exercise is a physiological state that increases release of mediators (serotonin, bradykinin and endorphins), which sensitize the calcium ion channel through which histamine works, the transient receptor potential vanilloid 1 (TRPV1) receptor [54]. This ion channel is present on both sensory nerves and mast cells. Acidosis and rise in core body temperature also directly agonize the TPRV1 ion channel to further reduce the activation threshold to allergic products [54]. ATP, which increases with exercise, inhibits the homeostatic de-activation of TRPV1 receptor [55].

\section{Intercurrent illness}

Infective illness has similar metabolic influences as exercise, and there is evidence of immunological vulnerability including mast cell activation [56]. The best data relating to food allergy and a reduced threshold for food with infective illness comes from food allergy oral immunotherapy reports, where doses of tolerated allergen have a higher rate of reaction during illness [57]. Hot showers have also been reported to be associated with risk of reaction to food allergens during immunotherapy [38]. Medications such as aspirin used to control symptoms and fever with infections might also contribute to risk of severe allergic reactions to food.

\section{Comprehension and education}

Anecdotal reports suggest there may be an effect of ethnicity on the incidence of allergic reactions to foods though it is unclear how this is mediated; it is possibly due to language and cultural difficulties inhibiting equivalent access to allergy focused clinical services and optimization of asthma care.

Education provided regarding food allergy and anaphylaxis will enhance the prevention, recognition and appropriate and timely therapy of anaphylactic reactions to food. The authors are aware from coroners' reports that learning difficulty (e.g., intellectual disability and language barriers) have been found to be issues in food anaphylaxis deaths.

\section{Other factors}

Many allergists recognize ethanol as risk factor for food allergy anaphylaxis, however, there is very little published literature on this $[58,59]$. Ethanol, like other recreational drugs, can be associated with reduced awareness, risk taking, and recognition of symptoms, as well as interfering with an individual's timely treatment response to severe food allergy. Physiologically, ethanol activates the TRPV1 channel, lowering the threshold to activation by the multiple endogenous products of the allergic response that act via this ion channel $[54,60]$. Activation of the TRPV1 ion channel on sensory nerves results in release of neuromediators including calcitonin nerve related peptide to cause vasodilation [61]. The vasodilation effect from ethanol could contribute to a more severe shock in food allergy. Alcohol may also cause gastritis, permitting greater allergen absorption.

Mastocytosis/mast cell tumors/mast cell activation should be included in underlying risk factors for severity of anaphylaxis in general, however, we are not aware of a food allergy death being reported in a patient with documented mastocytosis/mast cell activation syndromes.

\section{In summary}

There are many layers to the risk of severe reactions in food allergy. A model of augmenting factors has recently been suggested [62]. We have developed 2 frameworks to consider risk factors. These co-contributors are summarized in Fig. 1. More severe and fatal reactions are likely to occur 


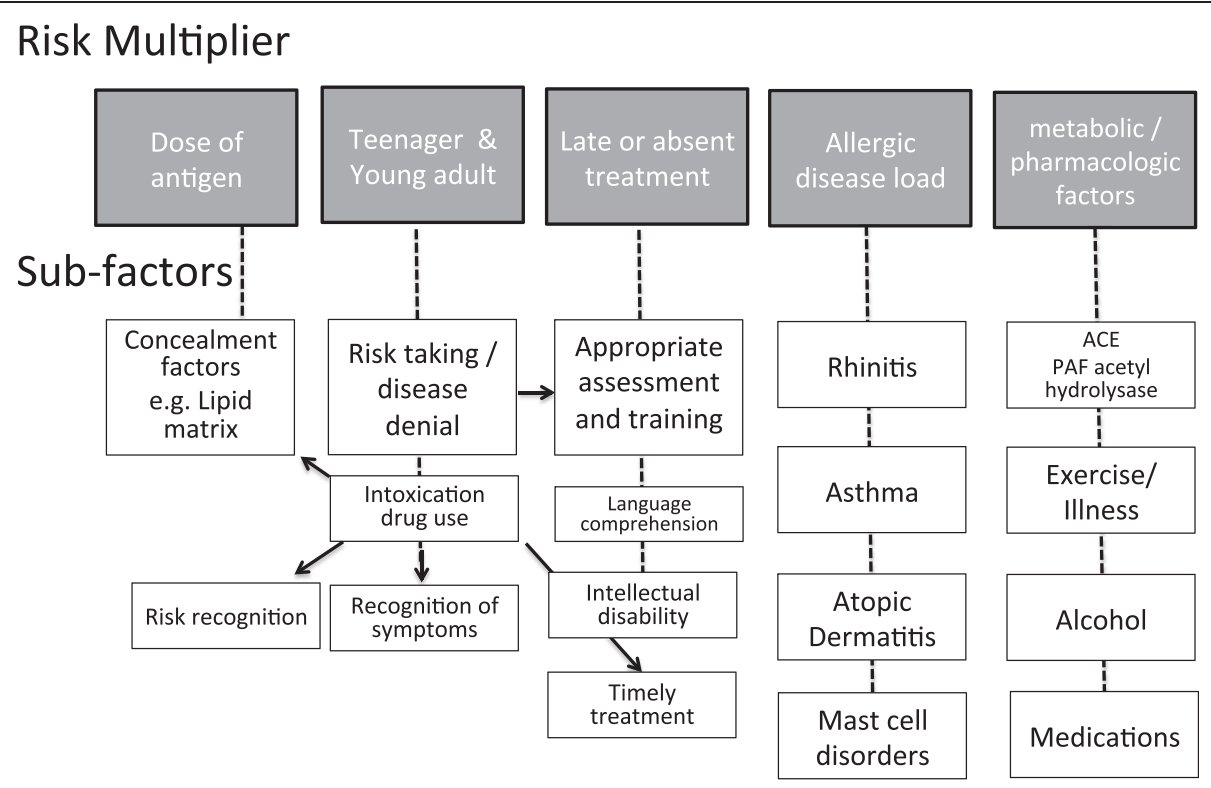

Fig. 1 Layers and multiplication factors relating to risk in severe food allergy: 1. Dose of antigen, which can be altered by concealment factors, 2. Age-most deaths from food allergy are in the young, but older patients tend to have more severe reactions with nut allergy, 3. Timely effective treatment, 4. Co-existent allergic burden, and 5. Metabolic/Pharmacologic factors including: capacity to catabolize allergic mediators, exercise, illness, ethanol and medications.

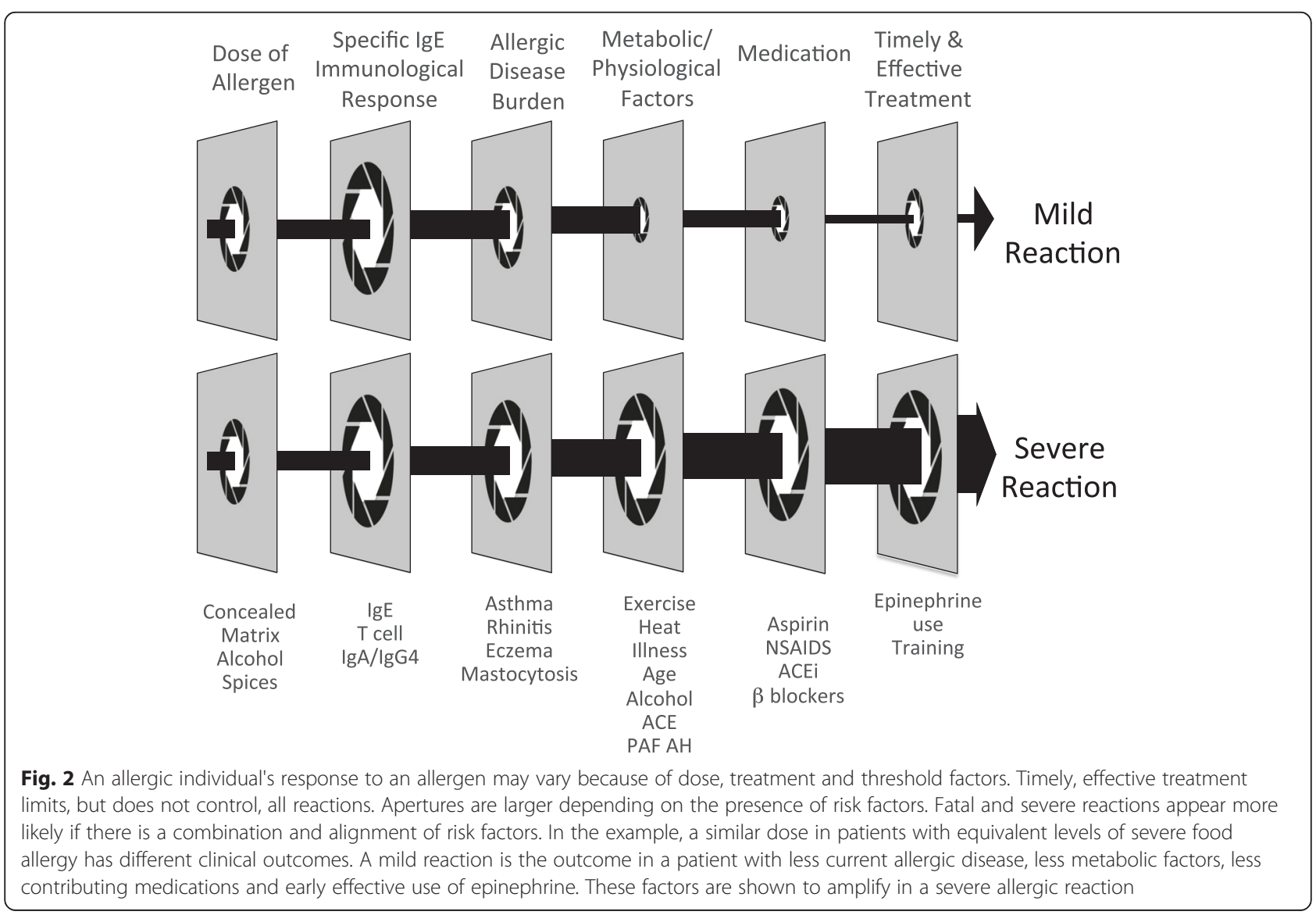


with alignment of these layers-the so-called "swiss-cheese" model, and a gap emerges. A larger aperture to "fall through" opens with more risk factors, and the result is likely to be a severe reaction if there is alignment (Fig. 2). The role of the allergy specialist is critical in risk identification, the communication of risk, treatment of comorbidities and having a supportive, empowering and effective management plan in place with medications on hand for patients and families to self treat when accidentally exposed to food and other allergens.

\section{Competing interests}

This works is unfunded and no authors have a conflict of interest.

\section{Authors' contributions}

PS and JOH conceived the framework of the manuscript. All authors helped draft and develop themanuscript and the summative figures. All authors have read and approved the final manuscript.

\section{Author details}

${ }^{1}$ Griffith School of Medicine, Gold Coast, Australia. ${ }^{2}$ University College Cork, Cork, Ireland. ${ }^{3}$ University of Tennessee College of Medicine, Memphis, Tennessee, USA.

Received: 6 August 2015 Accepted: 25 September 2015

Published online: 24 November 2015

\section{References}

1. Umasunthar T, Leonardi-Bee J, Hodes M, Turner PJ, Gore C, Habibi P, et al. Incidence of fatal food anaphylaxis in people with food allergy: a systematic review and meta-analysis. Clin Exp Allergy. 2013;43:1333-41.

2. Pumphrey RS. Lessons for management of anaphylaxis from a study of fatal reactions. Clin Exp Allergy. 2000;30:1144-50.

3. Bock SA, Mũnoz-Furlong A, Sampson HA. Fatalities due to anaphylactic reactions to foods. J Allergy Clin Immunol. 2001;107:191-3.

4. Simons FE, Ardusso LR, Bilò MB, El-Gamal YM, Ledford DK, Ring J, et al. World allergy organization guidelines for the assessment and management of anaphylaxis. World Allergy Organ J. 2011:4:13-37.

5. Bock SA, Muñoz-Furlong A, Sampson HA. Further fatalities caused by anaphylactic reactions to food, 2001-2006. J Allergy Clin Immunol. 2007;119:1016-8.

6. Klein JS, Yocum MW. Underreporting of anaphylaxis in a community emergency room. J Allergy Clin Immunol. 1995;95:637-8.

7. Wensing M, Penninks AH, Hefle SL, Koppelman SJ, Bruijnzeel-Koomen CA, Knulst AC, et al. The distribution of individual threshold doses eliciting allergic reactions in a population with peanut allergy. J Allergy Clin Immunol. 2002;110:915-20.

8. Hourihane JO'B, Kilburn SA, Nordlee JA, Hefle SL, Taylor SL, Warner JO, et al. An evaluation of the sensitivity of subjects with peanut allergy to very low doses of peanut protein: a randomized, double-blind, placebo controlled food challenge study. J Allergy Clin Immunol. 1997;100:596-600.

9. Sicherer SH, Burks AW, Sampson HA. Clinical features of acute allergic reactions to peanut and tree nuts in children. Pediatrics. 1998;102, e6.

10. Grimshaw KEC, King RM, Nordlee JA, Hefle SL, Warner JO, Hourihane JO'B. Presentation of allergen in different food preparations affects the severity of the allergic reaction-a case series. Clin Exp Allergy. 2003;33:1581-5.

11. Eller E, Hansen TK, Bindslev-Jensen C. Clinical thresholds to egg, hazelnut, milk and peanut: results from a single-center study using standardized challenges. Ann Allergy Asthma Immunol. 2012;108:332-6.

12. Hourihane JO, Grimshaw KE, Lewis SA, Briggs RA, Trewin JB, King RM, et al. Does severity of low-dose, double-blind, placebo-controlled food challenges reflect severity of allergic reactions to peanut in the community? Clin Exp Allergy. 2005;35:1227-33.

13. Hompes S, Dölle S, Grünhagen J, et al. Elicitors and co-factors in food-induced anaphylaxis in adults. Clin Translational Allergy. 2013;3:38.

14. Yun J, Katelaris $\mathrm{CH}$. Food allergy in adolescents and adults. Intern Med J. 2009:39:475-8.
15. Sampson M, Munoz-Furlong A, Sicherer S. Risk taking and coping strategies of adolescents and young adults with food allergy. J Allergy Clin Immunol. 2006;117:1440-5.

16. Turner PJ, Gowland MH, Sharma V, lerodiakonou D, Harper N, Garcez T, et al. Increase in anaphylaxis-related hospitalizations but no increase in fatalities: An analysis of United Kingdom national anaphylaxis data, 1992-2012. J Allergy Clin Immunol. 2014. doi:10.1016/j.jaci.2014.10.021.

17. Brown SG, Stone SF, Fatovich DM, Burrows SA, Holdgate A, Celenza A, et al. Anaphylaxis: clinical patterns, mediator release, and severity. J Allergy Clin Immunol. 2013;132:1141-9.

18. Yunginger JW, Sweeney KG, Sturner WQ, Giannandrea LA, Teigland JD, Bray M, et al. Fatal food-induced anaphylaxis. JAMA. 1988;260:1450-2.

19. Sampson HA, Mendelson LM, Rosen JP. Fatal and near-fatal anaphylactic reactions to food in children and adolescents. N Engl J Med. 1992;327:380-4.

20. Pumphrey RSH, Stanworth SJ. The clinical spectrum of anaphylaxis in north-west England. Chn Exp Allergy. 1996;26:1364-70.

21. Mehra S, Salter J, Sussman G, et al. A study of 32 food-related deaths from anaphylaxis: Ontario; 1986-2000. J Allergy Clin Immunol. 2002;101:S181.

22. Gu X, Simons KJ, Johnston $L$, et al. Can epinephrine inhalations be substituted for epinephrine injection in children at risk for systemic anaphylaxis? / Allergy. Clin Immunol. 2000;105:S276.

23. Simons FER, Roberts JR, Gu X, Simons KJ. Epinephrine absorption in children with a history of anaphylaxis. J Allergy Clin Immunol. 1998;101:33-7.

24. Simons FER, Gu X, Simons KJ. Epinephrine absorption in adults: intramuscular versus subcutaneous injection. J Allergy Clin Immunol. 2001;108:871-3.

25. Levy MB, Elizur A, Goldber MR, et al. Clinical predictors for favorable outcomes in an oral immunotherapy program for lgE-mediated cow's milk allergy. Ann Allergy Asthma Immunol. 2014;112:58-63.

26. Summers CW, Pumphrey RS, Woods CN, et al. Factors predicting anaphylaxis to peanuts and tree nuts in patients referred to a specialist centre. J Allergy Clin Immunol. 2008;121:632-8.

27. Pipkorn U, Enerback L. Nasal mucosal mast cells and histamine in hay fever. Effect of topical glucocorticoid treatment. Int Arch Allergy Appl Immunol. 1987:84:123-8.

28. Wachs M, Proud D, Lichtenstein LM, Kagey-Sobotka A, Norman PS, Naclerio RM, et al. Observations on the pathogenesis of nasal priming. J Allergy Clin Immunol. 1989;84:492-501.

29. Saini S, Bloom DC, Bieneman A, Vasagar K, Togias A, Schroeder J, et al. Systemic effects of allergen exposure on blood basophil IL-13 secretion and Fcepsilon RI beta. J Allergy Clin Immunol. 2004;114:768-74.

30. Naclerio RM, Proud D, Togias AG, Adkinson Jr NF, Meyers DA, Kagey-Sobotka A, et al. Inflammatory mediators in late antigen induced rhinitis. N Engl J Med. 1985:313:65-70.

31. Connell JT. Quantitative intranasal pollen challenge. II. Effect of daily pollen challenge, environmental pollen exposure, and placebo challenge on the nasal membrane. J Allergy. 1968:41:123-39.

32. Connell JT. Quantitative intranasal pollen challenges. 3. The priming effect in allergic rhinitis. J Allergy. 1969;43:33-44.

33. Baroody FM, Shenaq D, DeTineo M, et al. Fluticasone furoate nasal spray reduces the nasal-ocular reflex: A mechanism for the efficacy of topical steroids in controlling allergic eye symptoms. J Allergy Clin Immunol. 2009;123:1342-8.

34. Vetander M, Helander D, Flodström C, Ostblom E, Alfvén T, Ly DH, et al. Anaphylaxis and reactions to foods in children-a population-based case study of emergency department visits. Clin Exp Allergy. 2012;42:568-77.

35. Sicherer SH, Sampson HA. Food allergy. J Allergy Clin Immunol. 2010;125:S116-25.

36. Kleine-Tebbe J, Vogel L, Crowell DN, Haustein UF, Vieths S. Severe oral allergy syndrome and anaphylactic reactions caused by a Bet $\mathrm{V}$ 1-related PR-10 protein in soybean, SAM22. J Allergy Clin Immunol. 2002;110:797-804

37. Nguyen-Luu NU, Ben-Shoshan M, Alizadehfar R, Joseph L, Harada L, Allen M, et al. Inadvertent exposures in children with peanut allergy. Pediatr Allergy Immunol. 2012;23:133-9.

38. de Alwis MM, Lee J, Lester MR, Mendelson LM, Nouman G, Factor JM, et al. Predictors for allergic symptoms during build-up and maintenance phases of oral immunotherapy to peanut. J Allergy Clin Immunol. 2012. doi:10.1016/j.jaci.2013.12.382.

39. Pumphrey RSH, Gowland MH. Further fatal allergic reactions to food in the United Kingdom, 1999-2006. J Allergy Clin Immunol. 2007;119:1018-9. 
40. Worm M, Edenharter G, Ruëff F, Scherer K, Pföhler C, Mahler V, et al. Symptom profile and risk factors of anaphylaxis in Central Europe. Allergy. 2012;67:691-8.

41. Vadas P, Boris Perelman B, Gary Liss G. Platelet-activating factor, histamine, and tryptase levels in human anaphylaxis. J Allergy Clin Immunol. 2013;131:144-9.

42. Stone SF, Cotterell C, Isbister GK, Holdgate A, Brown SG, Emergency Department Anaphylaxis Investigators, et al. Elevated serum cytokines during human anaphylaxis: identification of potential mediators of acute allergic reactions. J Allergy Clin Immunol. 2009;124:786-92. e4.

43. Stafforini DM, Mclntyre TM, Carter ME, Prescott SM. Human plasma plateletactivating factor acetylhydrolase. Association with lipoprotein particles and role in the degradation of platelet-activating factor. J Biol Chem. 1987;262:4215-22.

44. Blais C, Marceau F, Rouleau JL, Adam A. The kallikrein-kininogen system: lessons from the quantification of endogenous kinins. Peptides. 2000;21:1903-40.

45. Varney VA, Warner A, Ghosh A, et al. IgE-mediated anaphylaxis to foods, venom, and drugs: influence of serum angiotensin converting enzyme levels and genotype. J Allergy. 2012. doi:10.1155/2012/258145.

46. Harada S, Horikawa T, Ashida M, Kamo T, Nishioka E, Ichihashi M, et al. Aspirin enhances the induction of type I allergic symptoms when combined with food and exercise in patients with food dependent exercise-induced anaphylaxis. Br J Dermatol. 2001;145:336-9.

47. Aihara M, Miyazawa M, Osuna H, Tsubaki K, Ikebe T, Aihara Y, et al. Food-dependent exercise-induced anaphylaxis: influence of concurrent aspirin administration on skin testing and provocation. Br J Dermatol. 2002;146:466-72.

48. Nassiri M, Babina M, Dölle S, Edenharter G, Ruëff F, Worm M, et al. Ramipril and metoprolol intake aggravate human and murine anaphylaxis: Evidence for direct mast cell priming. J Allergy Clin Immunol. 2015;135:491-9.

49. Beaudouin E, Defendi F, Picaud J, Drouet C, Ponard D, Moneret-Vautrin DA et al. Moneret-Vautrin DA.latrogenic angioedema associated with ACEi, sitagliptin, and deficiency of 3 enzymes catabolizing bradykinin. Eur Ann Allergy Clin Immunol. 2014;46:119-22.

50. Matsuo H, Dahlström J, Tanaka A, Kohno K, Takahashi H, Furumura M, et al. Sensitivity and specificity of recombinant omega-5 gliadin-specific lgE measurement for the diagnosis of wheat-dependent exercise-induced anaphylaxis. Allergy. 2008;63:233-6.

51. Matsuo H, Morita E, Tatham AS, Morimoto K, Horikawa T, Osuna H, et al. Identification of the lgE-binding epitope in omega-5 gliadin, a major allergen in wheat-dependent exercise-induced anaphylaxi. J Biol Chem. 2004;279:12135-40.

52. Shadick NA, Liang MH, Partridge AJ, Bingham III CO, Wright E, Fossel AH, et al. The natural history of exercise-induced anaphylaxis: survey results from a 10- year follow-up study. J Allergy Clin Immunol. 1999;104:123-7.

53. de Oliveira EP, Burini RC. Food-dependent, exercise-induced gastrointestinal distress. J Interl Soc Sports Nutri. 2011;8:12. doi:10.1186/1550-2783-8-12.

54. Smith PK, Nilius B. Transient Receptor Potentials (TRPs) and Anaphylaxis. Curr Allergy Asthma Rep. 2013;13:93-100.

55. Liu B, Zhang C, Qin F. Functional recovery from desensitization of vanilloid receptor TRPV1 requires resynthesis of phosphatidylinositol 4,5 bisphosphate. J Neurosci. 2005;25:4835-43.

56. Metz M, Maurer M. Mast cells-key effector cells in immune responses. Trends Immunol. 2007;28:234-41.

57. Jones SM, Pons L, Roberts JL, Scurlock AM, Perry TT, Kulis M, et al. Clinical efficacy and immune regulation with peanut oral immunotherapy. J Allergy Clin Immunol. 2009:124:292-300. e1-97.

58. Gonzalez-Quintela A, Vidal C, Gude F. Alcohol, IgE and allergy. Addict Biol. 2004:9:195-204.

59. Fiedler EM, Zuberbier T, Worm M. A combination of wheat flour, ethanol and food additives inducing FDEIA. Allergy. 2002;57:1090-1.

60. Trevisani M, Smart D, Gunthorpe MJ, Tognetto M, Barbieri M, Campi B, et al. Ethanol elicits and potentiates nociceptor responses via the vanilloid receptor-1. Nat Neurosci. 2002;5:546-51.

61. Nicoletti P, Trevisani M, Manconi M, Gatti R, De Siena G, Zagli G, et al. Ethanol causes neurogenic vasodilation by TRPV1 activation and CGRP release in the trigeminovascular system of the guinea pig. Cephalalgia. 2008;28:9-17.

62. Niggemann B, Beyer K. Factors augmenting allergic reactions. Allergy. 2014:69:1582-7.

\section{Submit your next manuscript to BioMed Central and take full advantage of:}

- Convenient online submission

- Thorough peer review

- No space constraints or color figure charges

- Immediate publication on acceptance

- Inclusion in PubMed, CAS, Scopus and Google Scholar

- Research which is freely available for redistribution

Submit your manuscript at www.biomedcentral.com/submit 